\title{
Investigating Large Igneous Province Formation and Associated Paleoenvironmental Events: A White Paper for Scientific Drilling
}

\author{
by Clive R. Neal, Millard F. Coffin, Nicholas T. Arndt, Robert A. Duncan, Olav Eldholm, \\ Elisabetta Erba, Cinzia Farnetani, J. Godfrey Fitton, Stephanie P. Ingle, Nao Ohkouchi, \\ Michael R. Rampino, Marc K. Reichow, Stephen Self, and Yoshiyuki Tatsumi
}

doi:10.2204/iodp.sd.6.01.2008

\section{Introduction}

Earth's history has been punctuated over at least the last 3.5 billion years by massive volcanism on a scale unknown in the recent geological past. Largely unknown mechanical and dynamic processes, with unclear relationships to seafloor spreading and subduction, generated voluminous, predominately mafic magmas that were emplaced into the Earth's lithosphere. The resultant large igneous provinces (LIPs; Coffin and Eldholm, 1994; Ernst and Buchan, 2001; Bryan and Ernst, 2008) were at times accompanied by catastrophic environmental changes. The interaction of the LIP-associated mantle processes with the Earth's crust have produced a variety of surface expressions (Fig. 1a and 1b); the most common present-day examples are oceanic plateaus (e.g., Kerguelen/Broken Ridge, OntongJava, Manihiki, Hikurangi, Shatsky), ocean basin flood basalts (e.g., Caribbean, Nauru), magma-dominated divergent continental margins (e.g., the North Atlantic), and continental flood basalts (e.g., Columbia River, Deccan Traps, Siberian Traps). Environmental effects associated with LIP formation include climate changes, mass and other extinctions, variations in ocean and atmospheric chemistry, and Oceanic Anoxic Events (OAEs). Therefore, the geodynamic processes in the mantle that produce LIPs have potentially profoundly affected the Earth's environment, particularly the biosphere and climate. The Integrated Ocean Drilling Program (IODP) affords unique opportunities to investigate LIPs and associated environmental effects, building upon results from the Ocean Drilling Program (ODP) and Deep Sea Drilling Project (DSDP) (Coffin et al.,
2006). To this end, a workshop on LIPs, sponsored by IODP Management International (IODP-MI) and the Consortium for Ocean Leadership, was held at the University of Ulster in Coleraine, Northern Ireland, U.K. on 22-25 July 2007 (Coffin et al., 2007).

A multi-disciplinary group of eighty scientists representing academia, government, and industry from sixteen countries discussed strategies for advancing understanding of LIPs and associated environmental events using the three different IODP platforms and related technologies. During the workshop, which began with an examination of the United Nations Educational, Scientific, and Cultural Organization (UNESCO) World Heritage "Giant's Causeway" exposure of the North Atlantic LIP (Fig. 2), scientists investigating LIPs through field, laboratory, and modeling approaches shared their expertise. Specifically, outstanding problems related to LIP origin, emplacement, and environmental impacts were discussed in plenary and breakout sessions. The workshop achieved the following:

- Identified multidisciplinary, synergistic approaches to addressing outstanding Earth system problems associated with LIP science.

- Brought together scientists from widely different areas of expertise (e.g., petrology, paleontology, geodynamics, oceanography, geophysics, logging, volcanology, geochemistry, stratigraphy, tectonics, paleoceanography, paleomagnetics) to focus on how ocean drilling can address unresolved issues associated with the origin,

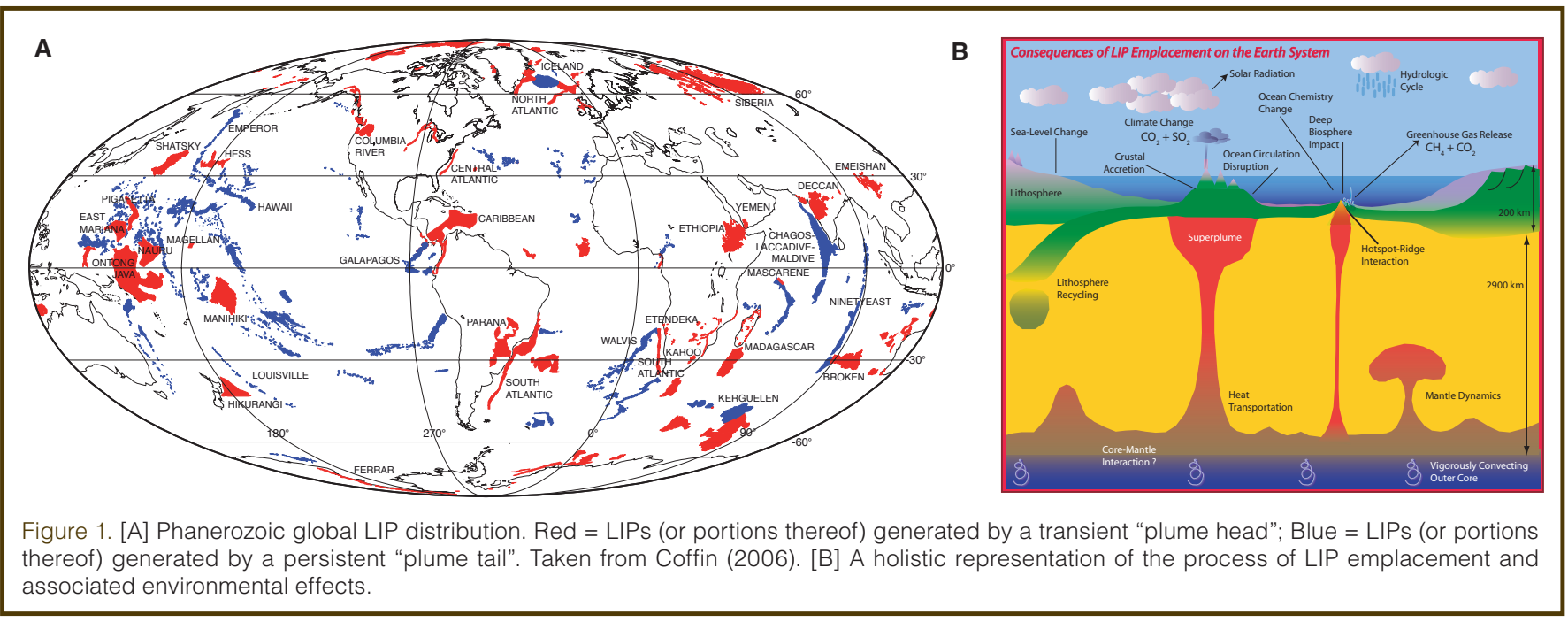


emplacement, and evolution of LIPs, as well as their impact on the environment.

- Exposed new scientists to the IODP and nurtured early career scientists, specifically with respect to how scientific drilling can advance understanding of LIPs.

- Enhanced cooperation between the IODP and the International Continental Scientific Drilling Program (ICDP).

- Explored partnerships among IODP, government, and industry.

One of the major outcomes of the workshop was to define multiple pathways to enhance our knowledge of LIPs through scientific drilling. These ranged from ancillary project letters, through individual expedition proposals, to a mission proposal.

This white paper highlights the major problems associated with LIPs that can be addressed through scientific drilling and related studies. It also highlights multidisciplinary approaches required to address such problems, as studies of LIPs encompass mantle geodynamics, emplacement processes, and environmental events affecting the lithosphere, hydrosphere, atmosphere, and biosphere.

\section{Past Achievements}

Scientific drilling has played a vital role in the exploration of LIPs, most importantly by providing the first, and in many cases the only, ground truth from the igneous basement of submarine LIPs. While major advances in LIP research involve holistic observational, experimental, and modeling studies involving a broad array of Earth science expertise, results from scientific drilling have been and will continue to be key components of interdisciplinary work. The first dedicated igneous basement sampling investigations of submarine LIPs, conducted during the ODP, concentrated on three provinces: the Ontong Java Plateau (Pacific Ocean), the Kerguelen Plateau/Broken Ridge (Indian Ocean), and the North Atlantic magma-dominated divergent continental margins (Fig. 1). Below, we highlight the major results of these investigations, which have laid the groundwork for the next major phase of discovery during the IODP.

Drilling results from 120-Ma Ontong Java Plateau basement rocks are complemented by studies of obducted plateau rocks exposed in the Solomon Islands (Andrews et al., 1975; Kroenke et al., 1991; Berger et al., 1993; Neal et al., 1997; Mahoney et al., 2001; Fitton et al., 2004a, b). All Ontong Java basement rocks recovered to date are remarkably homogeneous tholeiitic basalts with minor variations in elemental and isotopic composition, and they were deposited in a submarine environment. Partial batch melting $(\geq 30 \%)$ generated the basalts (Fitton and Godard, 2004; Herzberg, 2004), with melting and fractional crystallization at depths of $<6 \mathrm{~km}$ (Sano and Yamashita, 2004). The lavas and their overlying sediment indicate relatively minor uplift accompanying

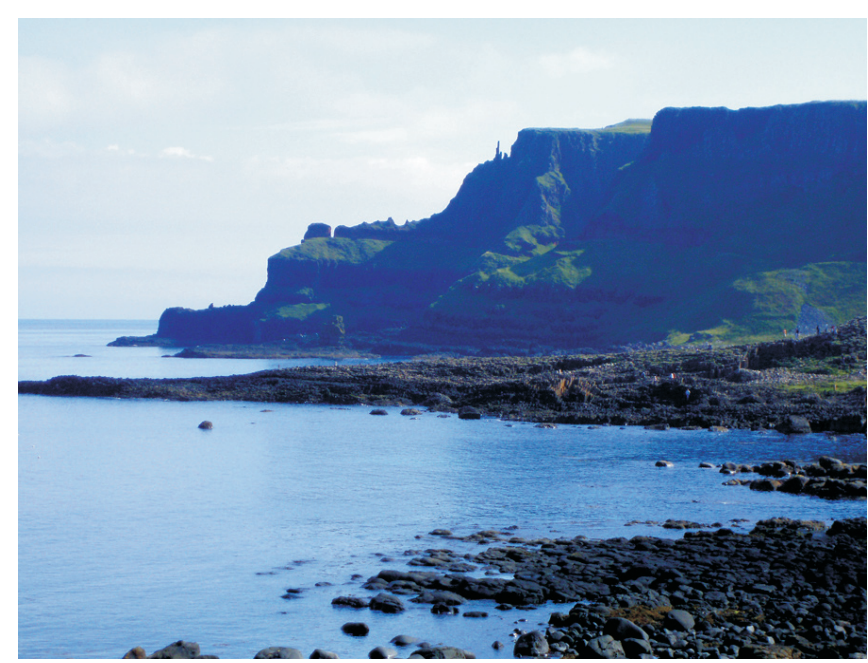

Figure 2. Giant's Causeway (Ireland), part of the North Atlantic LIP. Note the stepped topography in the background, characteristic of flood basalt provinces.

emplacement and relatively minor subsidence since emplacement. Primarily on the basis of drilling results, multiple models-plume (e.g., Fitton et al., 2004a), bolide impact (Ingle and Coffin, 2004), and upwelling eclogite (Korenaga, 2005) - have been proposed for the origin of the Ontong Java Plateau.

Uppermost igneous basement of the Kerguelen Plateau/ Broken Ridge is dominantly tholeiitic basalt erupted above sea level (Barron et al., 1989, 1991; Schlich et al., 1989; Wise et al., 1992; Coffin et al., 2000; Frey et al., 2003), and it shows two apparent peaks in magmatism at 119-110 Ma and 105-95 Ma (Coffin et al., 2002). Geochemical differences among tholeiitic basalts erupted at each site are attributable to varying proportions of components from the primary mantle source (plume?), depleted mid-ocean ridge basalt (MORB)-related asthenosphere, and continental lithosphere. Proterozoic-age zircon and monazite in clasts of garnet-biotite gneiss in a conglomerate intercalated with basalt at one drill site demonstrate the presence of fragments of continental crust in the Kerguelen Plateau, as inferred previously from geophysical (e.g., Operto and Charvis, 1995) and geochemical (e.g., Alibert, 1991) data. For the first time from an intra-oceanic LIP, alkalic lavas, rhyolite, and pyroclastic deposits were sampled. Flora and fauna preserved in sediment overlying igneous basement provide a long-term record of the plateau's subsidence, beginning with terrestrial and shallow marine deposition and continuing to deep water deposition.

Seaward-dipping reflector (SDR) wedges of the latest Paleocene-earliest Eocene North Atlantic LIP drilled off the British Isles during DSDP (Roberts et al., 1984), off Norway during ODP (Eldholm et al., 1987, 1989), and off SE Greenland during ODP (Duncan et al., 1996; Larsen et al., 1994, 1999) confirmed them to be thick series of subaerial lava flows covering large areas. Lavas on the landward side of the SDRs show geochemical and petrological evidence of contamination by continental crust, implying that they ascended through continental crust during early rifting, 


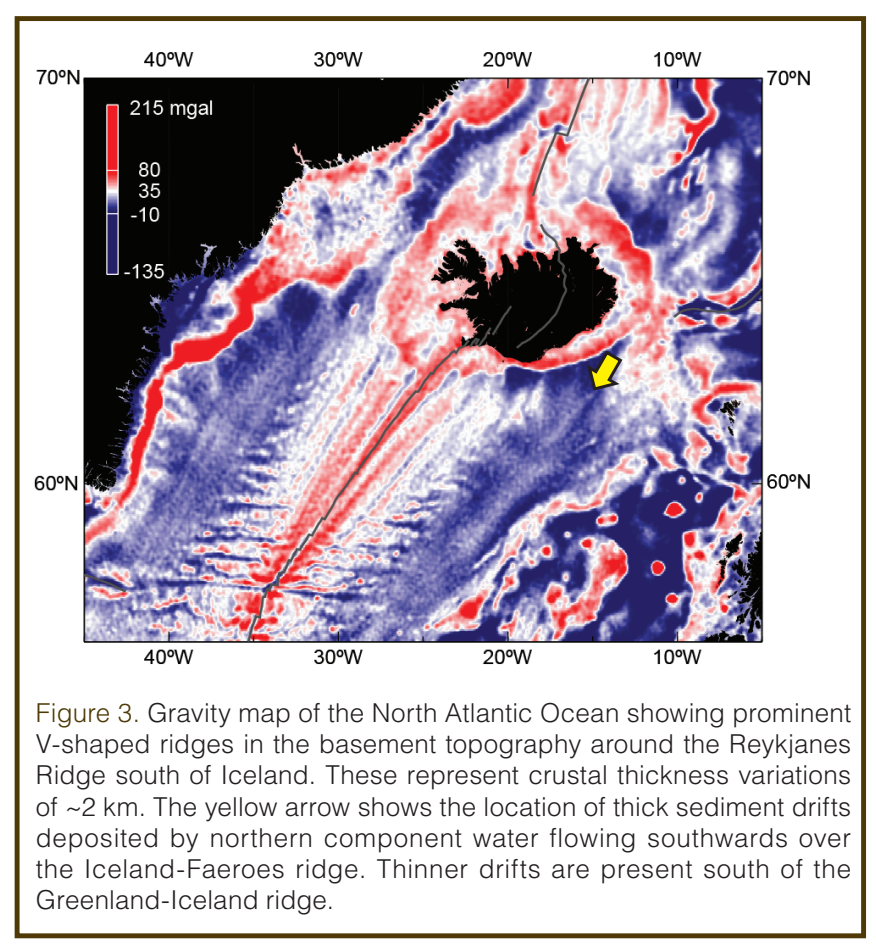

whereas oceanward SDR lavas appear to have formed at a seafloor spreading center resembling Iceland. Drilling results from these margins indicate extreme magmatic productivity over a distance of at least $2000 \mathrm{~km}$ during continental rifting and breakup, with spatiotemporal influence of the Iceland plume during rifting, breakup, and early seafloor spreading (Saunders et al., 1998).

\section{Mantle Geodynamics}

In many respects, LIP magmatism remains quite enigmatic, yet its unique characteristics (e.g., volumes of erupted lava, time duration of volcanism, distinct geochemical composition with respect to MORBs, and frequency over geologic time) unequivocally highlight the importance of understanding the underlying physical, chemical, mechanical, and dynamic processes.

The mantle plume model, in which dynamic instabilities of a thermal boundary layer (e.g., the $\mathrm{D}^{\prime \prime}$ zone at the base of the Earth's mantle) give rise to a mantle plume with a large head and a long-lived conduit or tail, provides a context for interpreting a wealth of surface observations related to LIPs and hotspot volcanism. And, if plumes do originate in the lowermost mantle, they may be the only way to 'sample' the deepest part of the Earth's mantle. Regardless of the origin of LIPs, studying them and hotspot volcanism provides unique and fundamental information about mantle dynamics, global heat and mass transfer in the mantle, time scales for 'storage' of geochemical heterogeneities and, ultimately, mixing efficiency of mantle convection.

Over the last decade, our views of mantle plumes have evolved considerably; the 'mushroom' shaped plume is certainly possible, but it is not the unique plume morphology. By moving beyond the simplistic assumption of a compositionally homogeneous mantle, where density differences are only due to temperature differences, numerical simulations and fluid dynamics laboratory experiments have found an astounding variety of plume sizes and shapes (Tackley, 1998; Davaille, 1999).

Although the nature of compositional heterogeneities in the Earth's mantle is still a matter of debate (e.g., recycled denser, eclogitic crust; early Earth crust; ancient mantle possibly interacting with the metallic core), many lines of seismological and mineral physics evidence suggesting the presence of chemically distinct, denser material in the lowermost mantle. Therefore, thermo-chemical plumes (i.e., their density contrast with respect to the surrounding mantle depends on both excess temperature and intrinsic composition) provide a new and exciting framework to relate deep mantle dynamics to LIP-forming events and pose a variety of new questions that can be addressed through scientific drilling.

\section{Mantle Temperature Versus Mantle Fertility in LIP Formation}

A primary question in understanding LIP formation is the extent to which melting anomalies reflect excess fertility in the mantle rather than excess mantle temperature. This issue lies at the heart of the current mantle plume debate. Mantle temperature can be addressed through the majorelement composition of primitive LIP basalt via phase equilibria (Herzberg et al., 2007), and studies thereof suggest excess temperatures of $<200^{\circ} \mathrm{C}$. Mantle fertility is more difficult to investigate because its effects can be mimicked by lower degrees of mantle melting. Diachronous V-shaped ridges around the Reykjanes Ridge south of Iceland (Fig. 3) provide an example of how this problem might be addressed. These ridges reflect fluctuations in crustal thickness of $\sim 2$ $\mathrm{km}$, and they are caused by pulses in magma productivity radiating outwards from the Iceland hotspot at $\sim 20 \mathrm{~cm} \mathrm{yr}^{-1}$. Drilling on the peaks and in the troughs along a transect away from the Reykjanes Ridge will allow basalt composition and hence mantle temperature estimates to be related to crustal thickness. Temperature fluctuations should result in an inverse correlation between gravity (a proxy for crustal thickness) and incompatible-element concentrations in basalt because these concentrations will be lower in largerdegree mantle melts. A direct correlation will indicate fertility pulses. A fluctuation in mantle temperature will cause a correlated fluctuation in water depth along the GreenlandIceland-Faeroes ridge, affecting the flow of northern component water southwards from the North Atlantic (Wright and Miller, 1996; Jones et al., 2002; Poore et al., 2006). Sediment drifts south of the Iceland-Faeroes ridge (yellow arrow in Fig. 3) should record variations in this flow, and coring these will provide an independent proxy for temperature fluctuations in the Iceland hotspot. This synergy between mantledynamic and paleoceanographic objectives will be of considerable mutual benefit. 


\section{Thermo-Mechanical Plume-Lithosphere Interaction with Massive Magmatism}

The amount of surface dynamic uplift induced by the arrival of a deep mantle plume is being widely debated. Pioneering models (e.g., Farnetani and Richards, 1994) suggested an unrealistically high uplift rate before volcanism, due to the following: (1) the assumption of purely thermal plumes, (2) poor representation of the lithosphere and the overlying crust, and (3) limited numerical resolution.

The plume uplift issue is currently being revisited using thermo-chemical plumes, which show a lower vertical velocity component than purely thermal plumes, and thus induce lower strain rates at the base of the lithosphere. Furthermore, the new generation of numerical models incorporates both a buoyant residual solid in the plume head resulting from partial melting, and surface exchanges of energy and mass between the ascending melts and surrounding rocks. For various plume buoyancy fluxes, lithospheric ages, and geodynamic settings, we can now calculate surface uplift/subsidence as a function of time and distance from the plume center. Model predictions should then be compared with geological observations obtained through drilling. It is important to emphasize that the geologically reconstructed time sequence of surface deformation needs to encompass a time interval extending from a few million years before to a few million years after the main phase of LIP construction.

Coupling of theoretical predictions with observations will lead to a self-consistent and coherent model of mantle plume dynamics and its thermo-mechanical effect on the overlying lithosphere. The periphery of the Ontong-Java Plateau (OJP) away from its convergent margin with the Solomon Islands may be ideal for this type of study. The OJP represents the world's most extensive LIP (equivalent to the size of Greenland or western Europe) that, on the basis of current knowledge, formed in $\sim 5$ myr at $\sim 122 \mathrm{Ma}$. It is divided into a High Plateau containing the bathymetric high and a seismically slow cylindrical mantle root extending to $\sim 300 \mathrm{~km}$ depth (Richardson et al., 2000; Klosko et al., 2001; Gomer and Okal, 2003) and an Eastern Salient (Fig. 4), with all drill sites encountering igneous basement being located on the High Plateau. Both isostatic (minimum) and dynamic (maximum) crustal uplift were significantly less for the OJP than for active hotspots today, and total subsidence is also anomalously less (Neal et al., 1997; Ito and Clift, 1998; Ito and Taira, 2000; Ingle and Coffin, 2004; Roberge et al., 2005) than that of any other known oceanic lithosphere (Parsons and Sclater, 1977; Coffin, 1992; Stein and Stein, 1992). However, to complicate this situation, ODP Leg 192 recovered a sequence of volcaniclastic sediments at Site 1184 on the Eastern Salient that represent subaerial eruptions (Thordarson, 2004); this is interesting because this site is not over the mantle root. The sequence was divided into several sub-units separated by wood horizons (Mahoney et al., 2001). Borehole heat flow measurements from the High Plateau and Eastern Salient will establish the thermal or chemical nature of the mantle root, and recovery of basement lava flows from the Eastern Salient will test whether volcanism was extensively subaerial in this area during formation of the OJP (consistent with plume theory), or whether the Site 1184 volcaniclastic sequence was produced by a late-stage volcanic edifice with the bulk of the Eastern Salient being constructed by submarine volcanism.

\section{LIP Internal Architecture}

Although drilling typically only scratches the surface of thick igneous basement, it is important to explore the internal structure of a LIP to quantify the relative volumes of extrusive versus intrusive magmatism (Cox 1992; Kerr et al., 1997). Better estimates of total melt volumes and compositions will help to bracket melting rates and to define melt transport/storage mechanisms between subsurface magma chamber(s) and the surface. Moreover, interactions between partial melts and the surrounding rocks determine the length- and time-scales over which LIP magmatism can change the temperature, the internal loads, and the state of stress of the pre-existing lithosphere and crust. LIPs emplaced in oceanic lithosphere (rather than the thicker and more compositionally complex continental lithosphere) are thus better suited to investigate the thermo-mechanical and compositional modifications induced by LIP magmatism in the lithosphere and the uppermost asthenosphere.

Moreover, we note that the current debate on the role of plumes in the formation of thick, subduction-resisting lithosphere in the Archean will benefit from a better characterization of the density and viscosity structure resulting from LIP volcanism. This may be difficult to achieve directly through scientific drilling, even with riser capability, although direct

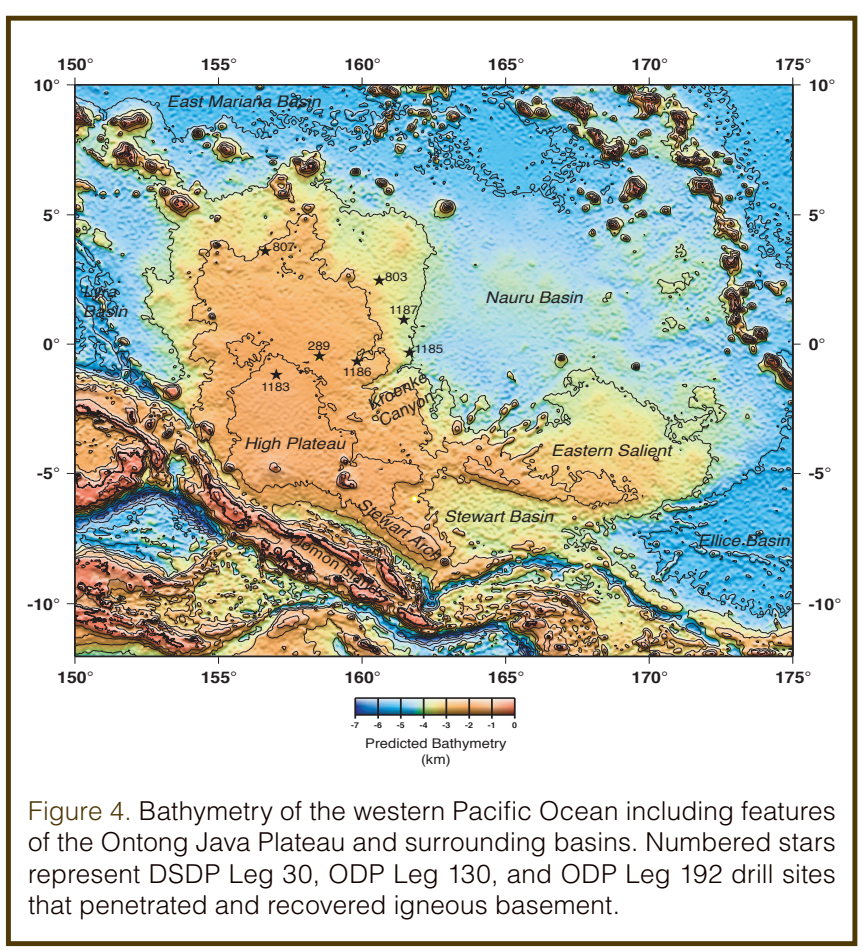


results of site survey work, done in preparation for drilling, can directly bear on this question.

\section{Plumes and Superplumes: Exploring Interactions with Slabs and the Earth's Core}

Although we generally consider plumes to be isolated 'bodies', they are part of mantle convection and are likely to interact with subduction processes and deep Earth dynamics. Plumes upwelling from the thermal boundary layer at the base of the Earth's mantle could enhance flushing of stagnant slabs into the lower mantle, and vice versa (Nakagawa and Tackley, 2005). During Cretaceous time, LIP and arc magmatism-which are surface manifestations of mantle upwelling and downwelling, respectivelyoccurred simultaneously (Reymer and Schubert, 1984; Larson, 1991; Eldholm and Coffin, 2000). Decoding the time relation between magmatism at LIPs and at convergent margins is, therefore, key to understanding the primary cause of mantle convection.

Recently, Burke and Torsvik (2004) restored twenty-five LIPs of the past 200 myr to their eruption sites using a new global paleomagnetic reference model. Ninety percent of the LIPs, when erupted, lay above low-velocity seismic-shearwave regions of the $\mathrm{D}^{\prime \prime}$ zone, as indicated in current tomographic models, suggesting that the deep mantle beneath the Central Pacific and Africa may represent a long-lived source region for plumes. Better characterization of LIPs will therefore help to understand the nature of 'superplumes', their stability over time ( $\geq 200$ myr?), and their potential to sample distinct geochemical reservoirs. By using 2-D numerical simulations, Farnetani and Samuel (2005) have shown the complex internal dynamics of thermo-chemical plumes, leading to the possible coexistence of different types of plumes and superplumes (Fig. 5).

Finally, the accumulation of cold slabs and the upwelling of hot material induce spatial and temporal variations in heat flow at the core-mantle boundary, affecting the outer core

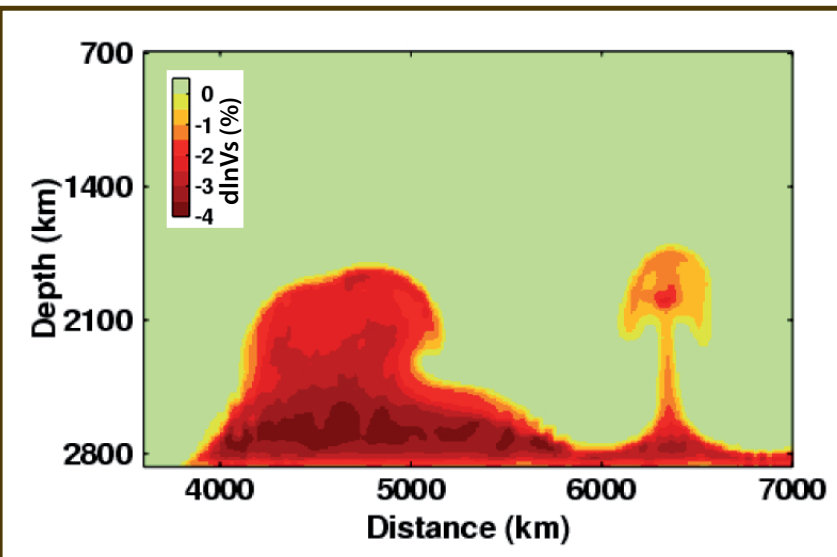

Figure 5. 2-D model showing the coexistence of plumes and superplumes in time and space (Farnetani and Samuel, 2005). Colors correspond to calculated seismic velocity anomalies (see inset key for quantitation). convection and the frequency of polarity reversals (e.g., low (high) core heat flux, infrequent (frequent) polarity reversals). Courtillot and Olson (2007) showed that three magnetic superchrons preceded the largest Phanerozoic mass extinctions (Cretaceous-Tertiary, Triassic-Jurassic, PermoTriassic), which are associated with major flood basalt events. These authors suggest that thermal instabilities in the $\mathrm{D}^{\prime \prime}$ layer may increase heat flow from the core and trigger the end of a magnetic superchron. Documenting the timing of LIP magmatism and superchron events will provide key information on dynamic linkages between the core and mantle.

\section{Geodynamics and Tectonic Setting}

LIPs are emplaced along active plate boundaries (e.g., magma-dominated divergent continental margins) and in intraplate settings (e.g., continental flood basalts). The tectonic setting of emplacement for most oceanic plateaus and ocean basin flood basalts, however, is not completely understood. A key question is whether upwelling mantle can erode the lithosphere sufficiently to instigate formation of a divergent plate boundary (Hill, 1991; Davies, 1994). While this appears to be the case for the North Atlantic volcanic province, where extension and seafloor spreading relocated from the Labrador Sea to the incipient northernmost North Atlantic coincident with massive North Atlantic volcanic province magmatism (Srivastava and Tapscott, 1986), the situation is significantly less clearfor other magma-dominated divergent continental margins (e.g., Northwest Australia and Kerguelen/Antarctica/India/Australia). To gain a thorough understanding of relationships among mantle geodynamics, tectonics, and basaltic magmatism, we need to investigate more than a single example of magma-dominated divergent margins by scientific ocean drilling.

In marked contrast to the North Atlantic example, the Northwest Australian margin is segmented, and igneous rock volumes vary considerably along strike, without clear evidence for a related mantle plume (Mutter et al., 1988; Hopper et al., 1992; Symonds et al., 1998; Planke et al., 2000). This makes the margin a strong candidate to test the edgedriven/small-scale convection hypothesis (Mutter et al., 1988; King and Anderson, 1998; Korenaga, 2004) for generating excessive magma by drilling a margin transect across multiple seaward-dipping reflection wedges, the Wallaby Plateau, and normal oceanic crust. The geochemistry, petrology, and geochronology of the recovered rocks will yield melting conditions, mantle reservoir type, extent of continental contamination, and the spatiotemporal evolution of the magma source.

The Kerguelen Plateau/Broken Ridge appears to have begun forming in the nascent eastern Indian Ocean at least 10 myr after breakup among Antarctica, India, and southwestern Australia (Coffin et al., 2002; Gaina et al., 2007). Despite these conjugate continental margins exhibiting 
some characteristics of excessive magmatism during breakup (e.g., SDR wedges; Stagg et al., 2007) and contemporaneous continental basaltic volcanism (Storey et al., 1992; Frey et al., 1996), the lack of physical and therefore geochronological continuity between these margins and the Kerguelen Plateau/Broken Ridge reveals yet another variation from the North Atlantic example of simultaneous continental breakup and LIP formation. Drilling the Early Cretaceous SDR wedges of the conjugate southwest Indian Ocean margins and the oldest portions of the Kerguelen Plateau to determine geochemistry, petrology, and geochronology will address critical questions involving relationships between geodynamics and tectonic setting.

\section{Emplacement}

Unravelling the emplacement of LIPs is pivotal in understanding their significance in the formation of the Earth's crust as well as any potential environmental consequences. Our understanding of these processes remains quite limited, and basic questions - such as whether or not the centers of these eruptions occur along fissures-are still matters for debate. Onset of volcanism can be determined for most continental LIPs, although cessation of activity is more problematic to determine due to erosion of uppermost lavas. Oceanic LIPs provide a unique opportunity to address these issues as they are generally better preserved, and consequently can provide a more complete picture of LIP formation. The major issue concerns timing of LIP generation and emplacement (i.e., whether the event was short- or long-lived). We observe examples of both in almost wholly submarine LIPs and in subaerially emplaced LIPs that have been partly rifted and submerged. This overarching question encompasses several missing links in our present understanding that are immediately addressable by scientific drilling.

\section{Duration of Emplacement}

Many LIPs appear to have at least one major pulse of volcanism when the most voluminous lava sequence was erupted. Identifying the duration of the full sequence of lavas enables identification of the most voluminous intervals. Knowing the time span of the most voluminous interval(s) for each LIP is crucial for determining the mechanism of emplacement and the potential environmental impact. Furthermore, sampling and dating the lavas allow questions concerning episodicity (about which we know little in major LIPs) to be addressed. For example, was there more than one interval of voluminous volcanism associated with the LIP's formation? As well as from direct sampling of LIP lavas, much can be learned about the onset and cessation of LIP volcanism from environmental indicators contained in sedimentary sections in older basins adjacent to the LIPs and (potentially) worldwide. These include shifts in isotopic and trace metal content of the sediment that can be linked to the arrival of the first LIP lavas onto the seafloor and/or (perhaps) volcanic degassing to the atmosphere. If the sedimen- tary sequence yields a high-resolution record, this can provide a highly sensitive time indicator of the onset and cessation of LIP activity, directly correlating the LIP with any contemporaneous environmental events.

\section{Style and Timing of LIP Eruptions}

Many eruptions occur during the lifespan of a LIP. For almost all LIPs, the total volumes of lavas are not accurately known, let alone those contained in each eruptive package (or other volcanic deposits such as hyaloclastites). What is also unknown is whether each package was produced by short, intense eruptive episodes, or more pulse-like and protracted ones. Critical for addressing environmental recovery is accurate determination of intervals between eruptions. Drilling into LIPs will provide samples of sediment between lavas to address this (e.g., ODP sites 642 and possibly 807; Larson and Erba, 1999). The probability of finding chronological and environmental markers (e.g., carbonaceous or siliceous sediment deposition) between flow units is much higher in the oceanic environment than on the continents. Erosion during emplacement of submarine LIPs is expected to be minimal; hence, it is more likely to recover flows erupted in sequence. Furthermore, the final (uppermost) lavas are commonly not preserved in continental flood basalts, but truly submarine LIPs offer a much greater chance of obtaining the full sequence of lava products, or at least the last erupted lavas.

If these two fundamental problems can be addressed, we will be able to answer questions such as:

1) When was the big pulse or biggest pulses of volcanism during a LIP's lifespan?

2) Does this time correlate globally with sudden environmental events?

3) What possible role(s) does LIP emplacement have on these sudden events?

Timing of emplacement is critical for determining magma fluxes and, ultimately, the mantle processes controlling magma production. Is magma production in plume heads controlled by 'bottom-up' or 'top-down' processes? To better understand the possible effects of LIP volcanism being causal for brief but severe environmental crises, it is necessary to determine eruption rates, and this, in turn, will be useful to model the transport and emplacement distances of lava flows.

\section{Consequences of Shallow Intrusions}

Another topical and critical question concerns LIP-related sill emplacement into sediments leading to gas release into the ambient environment; this has occurred on land and on the ocean floor (Svensen et al., 2004). Would submarine gas or fluid release directly affect the oceanic environment (Fig. 6)? To better examine relationships between sills and 
lava flows, drilling in specific areas can address the timing of the intrusion of the sills, whether they were the feeders for the flood lavas (see section Duration of Emplacement above) and plumbing systems for LIPs. If the sills and their interactions with sediment cause environmental changes, then it is vital to establish the timing of sill and LIP lava emplacement. Further to the consideration of sills, we know little about magma reservoirs for LIPs, including their locations and dimensions. Are the chambers deep or shallow? Perhaps in oceanic crust, more primitive magmatic material can be erupted at the surface that would otherwise be stalled in continental crust, and a study of this may provide clues to the nature of the initial magmatism related to LIPs.

\section{Relationships Between Subaerial and Submarine LIP Emplacement}

What are the differences between subaerial and submarine emplacement of LIP lavas, and thus the similarities or differences in LIP architecture between the continental and oceanic realms? In the ocean, very large flow fields may be possible underwater, and perhaps few barriers halt the spread of lava flows. We might thus predict widespread lava fields covering whole provinces, but is this realistic? What do LIP super-eruption products look like when they are emplaced under water? Are the component lava bodies of oceanic flow fields similar in dimension to those in continental flood basalt provinces, with flow unit thicknesses of $100 \mathrm{~m}$ or greater? What is the overall architecture of an oceanic plateau sequence? It appears that their dominantly shallow dipping, low angle slopes would favor the inflation of lava flows (Self et al., 1998).

Lava age distributions are also needed to assess how LIPs are constructed. Even though younger, post-major pulse lavas cover most oceanic LIPs, it may be possible to find widespread main-pulse lavas at the edges of LIPs. Using the architecture of better-known subaerial LIPs (Fig. 7), we can assess where best to drill to intersect long lava flows in submarine LIPs.

An important aspect of subaerial versus submarine emplacement of LIPs is the nature of seaward-dipping reflectors (SDRs). These are highly significant components of several LIPs (such as the North Atlantic and Kerguelen) and not observed in continental LIPs. They are most likely related to the tectono-magmatic setting, but what do they represent? Are they exclusively subaerially emplaced, but subsided parts of a LIP, or might they also form in marine environments? Some geophysical observations suggest the latter, but confirmation by ocean drilling is required. To understand the nature of SDRs, it is crucial to drill full sequences to determine if these were emplaced as deep marine sheet flows, perhaps infilling a subsiding rift basin.

\section{LIP-Generated Felsic Magmas}

Felsic volcanic rocks are typically much higher in potassium than their mafic counterparts and thus contain ideal minerals for Ar-Ar dating. Drilling on the Kerguelen

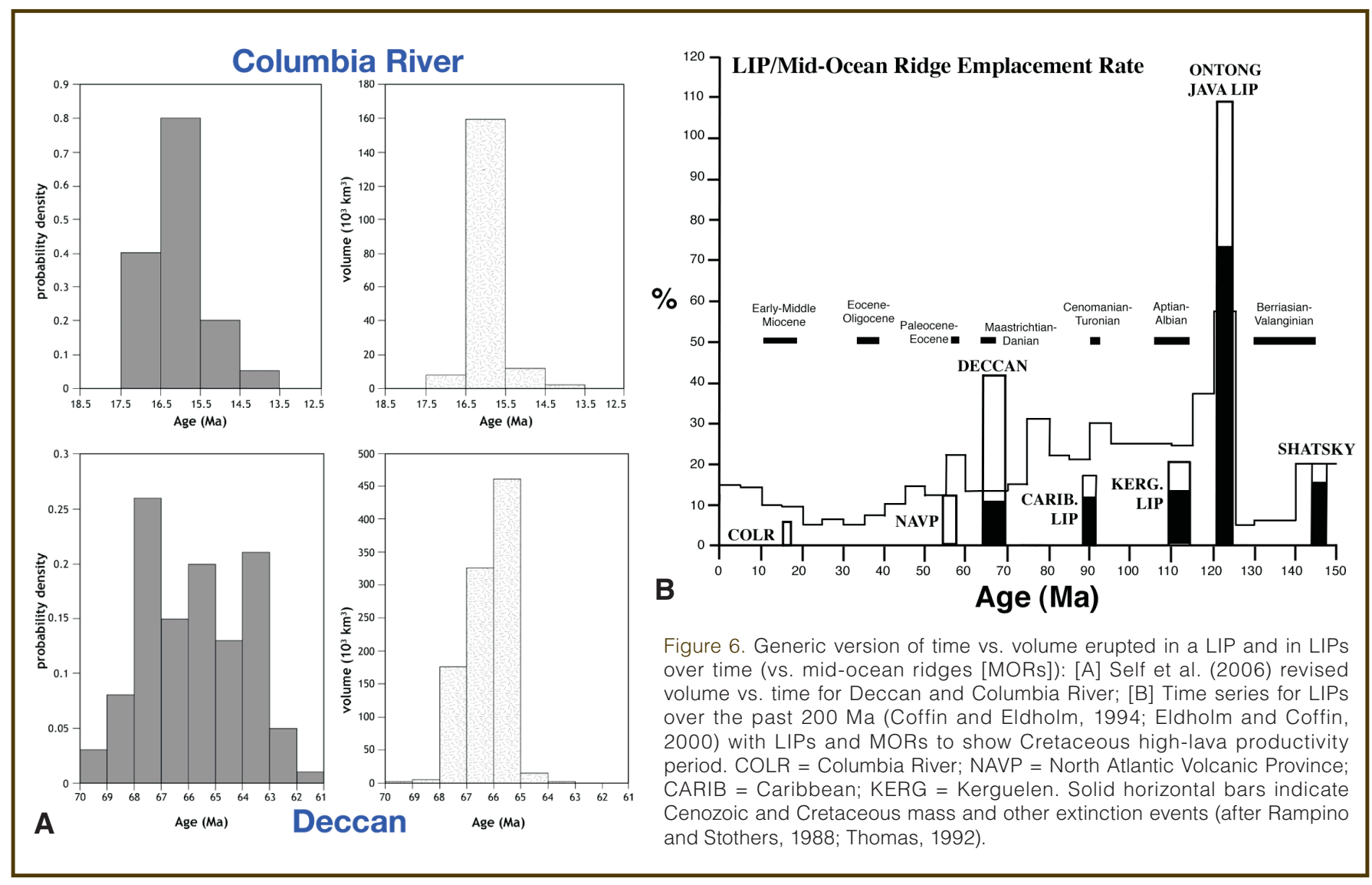


Plateau (ODPLeg 183) recovered significant amounts of a wide variety of felsic volcaniclastics and lavas (Coffin et al., 2000). Other oceanic LIPs, such as Hess Rise in the Pacific (DSDP Leg 62), contain discrete intervals of felsic lavas. Many, if not all, continental LIPs contain felsic components in the mainseries lavas (Bryan et al., 2002), but not from the Deccan and the Columbia River provinces. Eruptions of these evolved magmas can be explosive (e.g., the Ethiopian ignimbrites) and represent valuable stratigraphic and geochronologic markers if they can be correlated to felsic ash fall deposits in deep sea sediment (Peate et al., 2003).
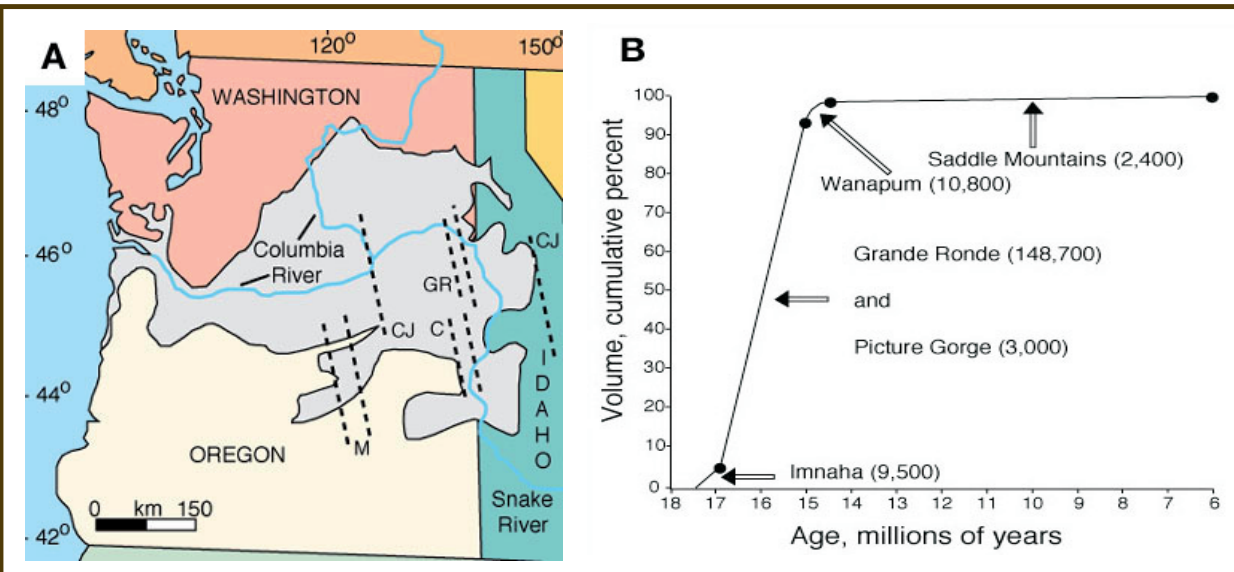

Figure 7. [A] Map of the Columbia Plateau, showing the limits of the Columbia River flood basalts and the feeder dike systems (dashed lines). CJ indicates the longitudinal boundaries of the Chief Joseph dike swarms that fed the Clarkston (Imnaha, Grande Ronde, and Wanapum) and Saddle Mountain basalts. The Grande Ronde (GR) and Cornucopia (C) swarms are concentrations within the CJ. M indicates the Monument dike swarm that fed the Picture Gorge basalt. [B] Ages and estimated volumes of the major eruptive units of the Columbia River basalts. This figure illustrates that surficial sampling of a LIP can yield information on its history of formation.

Drilling into felsic volcanic products of LIP volcanism, on both the LIP proper and in neighboring sedimentary sections, will help anchor the timing of eruptions via chronostratigraphy.

\section{Environmental Consequences}

Connections between large historic basaltic eruptions and perturbations of the global environment are well documented. Classic examples include the eruptions of Laki, Iceland in 1783, and Eldgjá, Iceland in 934, both of which were followed in subsequent years by historically cold summers in the northern hemisphere (Stothers, 1998). In contrast, LIPs represent much larger outpourings of basaltic magmas over much longer time scales, and recent data (Coffin and Eldholm, 1994; Kerr, 1998; Larson and Erba, 1999; Leckie et al., 2002; Snow et al., 2005; Kuroda et al., 2007) increasingly suggest temporal correlations between LIP formation and significant oceanographic, biotic, and climatic events, the most severe of which are OAEs. Greenhouse gases released from LIP magmas, as well as sedimentmagma interactions and ocean chemistry changes associated with the LIP emplacement, may have had major effects on the global environment (Fig. 1b). Critical in understanding the impact LIP magmatism may have had on the environment is determining LIP volume and, more importantly, magma eruption rates. Scientific drilling has a vital role to play in identifying the mechanisms and quantifying the timescale and magnitude of effects, and interdisciplinary, synergistic collaborations among scientists from a variety of disciplines are required.

\section{Atmospheric Impacts of LIP Emplacement}

LIPs may impact the atmosphere, oceans, and biosphere by rapidly releasing huge amounts of magmatic volatiles
$\left(\mathrm{CO}_{2}, \mathrm{SO}_{2}\right.$, etc. $)$ or volatiles $\left(\mathrm{CO}_{2}, \mathrm{CH}_{4}\right)$ from intruded sediments (e.g., carbonates, organic-rich shales, evaporites) (Fig. 8). Directly or indirectly, they may cause changes in the atmosphere/ocean system that lead to perturbations of atmosphere/ocean chemistry, circulation, ecology, and biological productivity (Self et al., 2006). This was especially true in Cretaceous and Early Tertiary time, when the atmospheric $\mathrm{CO}_{2}$ content of the atmosphere was three to seven times higher than that of today (Fig. 9), and perhaps more susceptible to short-term perturbations in ocean/atmosphere dynamics and their ensuing effects on life. Furthermore, recent compilations suggest that a sudden sea level rise ( $\sim 60 \mathrm{~m}$; Miller et al., 2005) was associated with the Paleocene-Eocene Thermal Maximum (PETM) event (Kennett and Stott, 1991; Bains et al., 1999; Svensen et al., 2004), which in turn was concurrent with the formation of the North Atlantic Volcanic Province (Eldholm and Thomas, 1993).

\section{Oceanic Anoxic Events}

Episodes of complete depletion of oxygen below surface levels in the Earth's oceans, known as OAEs (Schlanger and Jenkyns, 1976), represent the most momentous environmental changes in the ocean of the past 250 million years, and bear some similarities to the less impactive PETM event. Examples of linked LIP emplacement and major environmental/biological crises include (Fig. 10): Oceanic Anoxic Event (OAE)-1a in the early Aptian ( 122 Ma) and the Ontong Java Plateau ( 120 Ma), Manihiki Plateau $(\sim 120 \mathrm{Ma})$ and the Kerguelen Plateau ( 119Ma);OAE-2 around the CenomanianTuronian boundary ( $94 \mathrm{Ma})$ and the Caribbean-Colombian flood basalts ( 92-94 Ma); and the PETM (55 Ma) and the North Atlantic Volcanic Province ( $55 \mathrm{Ma})$.

There are two possible causal relationships between LIPs and OAEs: 1) the instigation of oceanic anoxia through global 
warming by greenhouse gases (e.g., $\mathrm{CO}_{2}, \mathrm{CH}_{4}$ ) that leads to ocean stagnation, which in turn induces anoxia in deep/ intermediate depths of the ocean; and 2) submarine volcanic eruptions and associated massive hydrothermal release of trace metals into the global ocean instigating black shale events (Snow et al., 2005). Furthermore, the connection between LIPs and marine biotic changes (including some extinctions) has been ascribed to acidification of seawater by adding $\mathrm{CO}_{2}$ and $\mathrm{SO}_{2}$ (Coffin and Eldholm, 1994; Kerr, 1998). However, these ideas require critical evaluation.

\section{Exploring Linkages between LIP Emplacements and Environmental Events}

To evaluate linkages between LIP emplacements and environmental events requires information on multiple topics:

1) Accurate and precise timing, duration, and magnitude of LIP magmatic activity and environmental/biotic perturbations;

2) Volatile fluxes related to LIP emplacement events (i.e., LIP magma degassing as well as those potentially derived from magma-sediment interactions) and the extent of gas release into the ocean/atmosphere environment;

3) Hydrothermal fluid compositions (especially trace metals) and fluxes related to LIP emplacement events, and the extent of their release into the ocean environment;

4) Eruptive environments (e.g., deep/shallow submarine; subaerial) and sediment-magma interactions, as well as the overall tectonic settings, of LIP events;

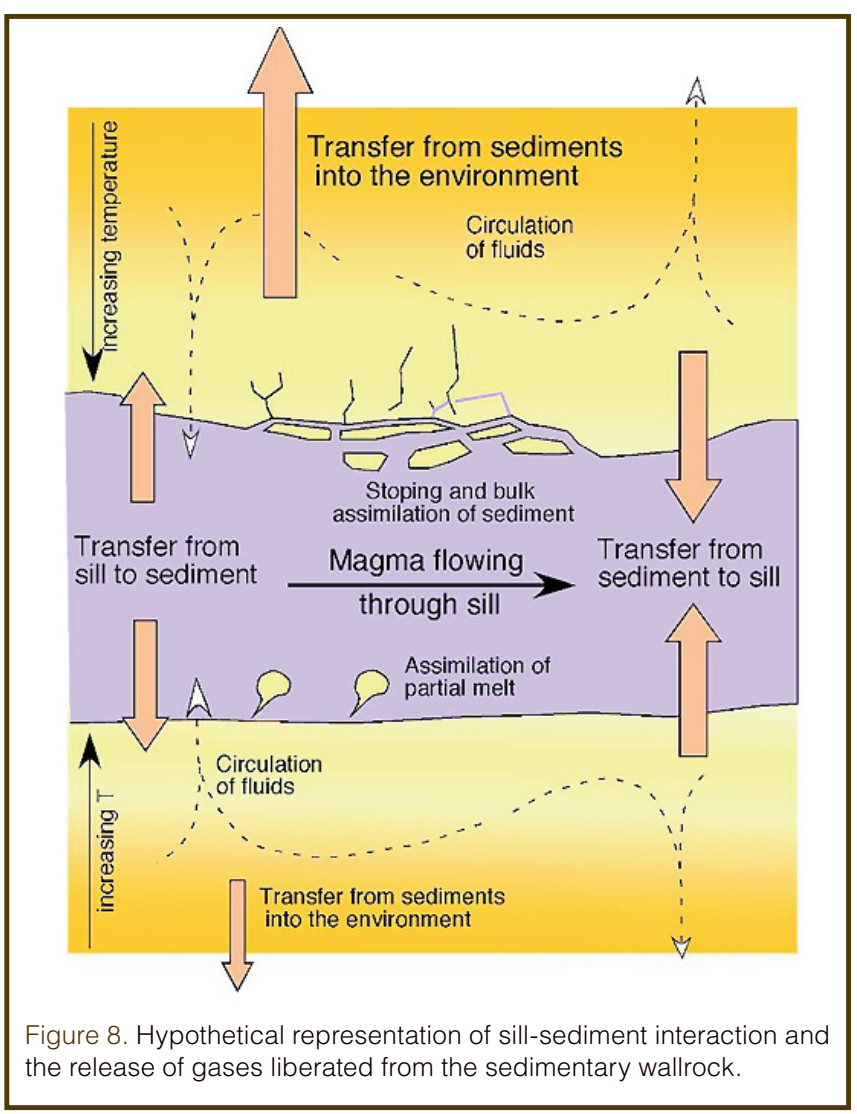

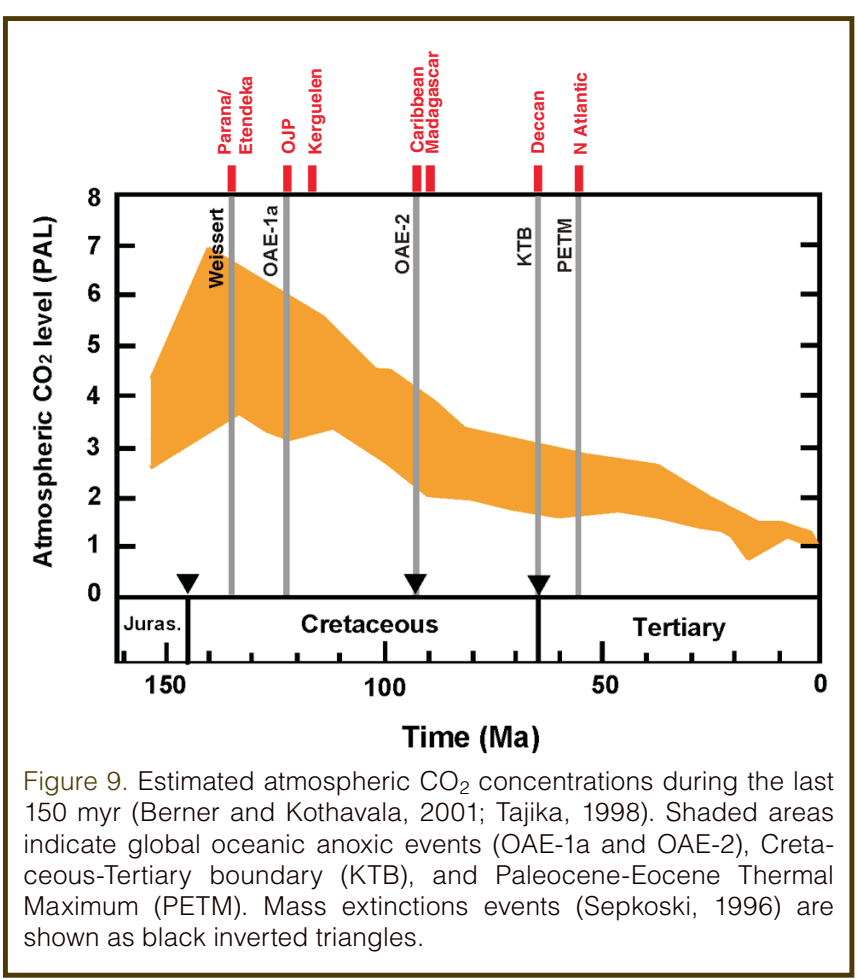

5) Specific paleoenvironmental conditions prior to, at the onset of, and during times of LIP emplacements (i.e., to define changes in atmospheric and oceanic physical and chemical properties and circulation).

Temporal coincidence between LIPs and environmental crises is clear for a few examples (e.g., North Atlantic LIP, Deccan Traps, Siberian Traps), but temporal correlations between others need further evaluation.

Sediment and volcanic rock recovered by the IODP in various oceanic basins and at different paleolatitudes will provide opportunities to resolve these issues in the following ways:

- Obtaining complete, high-resolution sedimentary records from critical ocean environments (e.g., the Mesozoic pelagic/deep, shallow, and atoll; sediment from the Pacific, Indian, Arctic, and Southern oceans; and high paleo-latitudinal sites are critically required).

- Obtaining syn-sedimentary sections within or adjacent to individual LIPs to estimate the potential hydrothermal fluid release and gas release through sedimentmagma interactions.

- Targeted drilling to bracket the duration, peak, and volume of magmatic activity (e.g., tectonic windows and feather edges of LIP basement, and syn-sedimentary sections).

- Bracketing the chronology/duration of the environmental events through recovery of sedimentary sections containing carbonates at locations permanently above the carbonate compensation depth, or CCD (e.g., Magellan Rise). 


\section{New Approaches to Drilling of LIPs}

Global understanding of LIPs will benefit greatly from new approaches, with drilling as a key investigative tool. Such new approaches, detailed below, include strengthening collaboration with industry; more integrative, multidisciplinary studies; development and deployment of new technologies; and coordinated IODP-ICDP investigations.

\section{Industry Connections to Drill LIPs}

Drilling of LIPs is of interest to the hydrocarbon industry to understand the fundamental processes, in time and space, involved in LIP development and evolution. In particular, interest focuses on how these processes influence the thermal, structural, depositional, and vertical motion histories of adjacent sedimentary basins (i.e., how LIPs influence the generation, maturation, and migration of hydrocarbons). Among the various LIP categories, the primary industry interest is magma-dominated divergent continental margins and, to a lesser degree, oceanic plateaus underlain, in whole or in part, by continental crust. Specific LIPs (e.g., the Norwegian, northwest Australian, and South Atlantic margins) are in regions of interest to the hydrocarbon industry, and ties with industry should be developed to the maximum extent possible.

Collaborative IODP-industry LIP investigations could take the form of industry-academia consortia established to address topics of interest to both industry and members of the IODP community using any of the three IODP platforms. Industry contributions to such consortia could include site surveying and seismic processing/reprocessing of existing seismic data using sophisticated techniques, as well as financial support for planning, execution, and interpretation phases of drilling programs.

Joint IODP-industry drilling ventures should address highly ranked scientific objectives, and the resulting data should be public domain, or offered to the community after a brief participant-exclusive period. Joint, dedicated LIP scientific drilling ventures provide a means to expand opportunities for scientific drilling while maintaining IODP scientific integrity.

\section{An Integrated Approach to Drilling LIPs}

LIP science will be advanced in five key areas by drilling, with objectives and potential drilling sites outlined below.

Obtaining deep sections within multiple LIPs to examine magmatic (and therefore mantle source) variability through time. This will require offset drilling along a rifted LIP margin or into a deep erosional feature within a LIP. Potential locations include (a) conjugate rifted margins of the Kerguelen Plateau and Broken Ridge, Indian Ocean; (b) conjugate rifted margins of the Hikurangi and Manihiki plateaus, Pacific Ocean; (c) Danger Islands Troughs of the Manihiki Plateau, Pacific Ocean; (d) proposed conjugate rifted margins of the Ontong Java Plateau bordering the Stewart Basin, Pacific Ocean; (d) Kroenke Canyon of the Ontong Java Plateau, Pacific Ocean; and (e) flanks of the TAMU Massif on the Shatsky Rise, Pacific Ocean. Note that as one of the oldest oceanic plateaus, Shatsky Rise is an important drilling target for increasing our understanding of the processes that form LIPs as well as how they evolve over time (e.g., subsidence history, secondary volcanism), although basalts from the feature are characterized by MORB-type isotopic signatures (Mahoney et al., 2005).

\section{Defining the nature of melting anoma-} lies (i.e., compositional vs. thermal) that produce LIPs. Understanding the underlying mechanics and dynamics of melting anomalies can be tested where basalt composition can be related to crustal thickness or where there is evidence for anomalous mantle beneath a LIP, such as (a) diachronous V-shaped ridges around the Reykjanes Ridge south of Iceland (Fig. 3) in the North Atlantic (see section Mantle Geodynamics above for rationale); and (b) Ontong Java's High Plateau, underlain by a $300-\mathrm{km}$-deep "root" of seismically anomalous mantle that has been
Figure 10. [A] A high-resolution profile of carbon isotopic composition of total organic matter from OAE-2 section from central Italy (Bonarelli Event, colored interval). Data from organicrich ( $>2 \%$ total organic carbon content) and -poor $(<2 \%)$ sediment are indicated by red and blue symbols, respectively. The profile indicates negative excursion at the base of the OAE-2. [B] A cross-plot of ${ }^{206} \mathrm{~Pb} /{ }^{204} \mathrm{~Pb}$ vs. ${ }^{208} \mathrm{~Pb} /{ }^{204} \mathrm{~Pb}$ in the Bonarelli (red symbols) and underlying Cenomanian limestone (blue symbols). For comparison, $\mathrm{Pb}$ isotopic compositions of basaltic rock from Caribbean (88-95 Ma), Madagascar flood basalts (88 Ma), and from MORB (present) from the Atlantic, Pacific, and Indian oceans are also shown. Both figures are referred from Kuroda et al. (2007). 
postulated to represent the fossil plume head of the OJP (Richardson et al., 2000; Klosko et al., 2001; Gomer and Okal, 2003). By determining heat flow from drill holes above the interpreted fossil plume head as well as away from it, the nature of the melting anomaly can be tested, as numerical models suggest that it should retain a detectable thermal signature.

Defining precise durations of oceanic LIP events. Two obvious ways to bracket LIP events are to (a) drill through the oldest and youngest eruptive sequences of a LIP, and (b) core a syn-LIP sedimentary sequence in an older proximal basin. Pursuing option (a) is not feasible by drilling through the entire eruptive sequence of a LIP, but if the age final eruption can be determined, the age of the start of LIP formation can be approximated by drilling through the lava flow sequence at the feather (distal) edge of a LIP. Option (b) will be pursued by drilling syn-LIP sedimentary sequences and analyzing for both age-dateable ash layers and chemical anomalies that are related to LIP formation and/or ash layers (taking into account the varying residence times in ocean water of different elements). Ideally, both options will be pursued. The feather edge of most oceanic LIPs may be drilled providing that it is distal to any volcanic vents and is not tectonic in nature. Examples of syn-LIP sedimentary sections in proximal basins include the following:

Kerguelen Plateau: Perth Basin off SW Australia, Enderby Basin and Princess Elizabeth Trough between Kerguelen and Antarctica;

Deccan Traps: Western and Northern Somali Basin west of Seychelles, where Deccan basalts crop out;

Agulhas Plateau: Transkei Basin between the Agulhas and Mozambique plateaus;

North Atlantic Volcanic Province: central and northern North Atlantic, ideally recovering sections through the Paleocene-Eocene Thermal Maximum event;

Shatsky Rise: Northwest Pacific Basin west of Shatsky Rise;

Ontong Java Plateau: Nauru Basin west of, and East Mariana and Pigafetta basins north of, the Ontong Java Plateau.

Moreover, the 145 -Ma Magellan Rise has a carbonate, chert, and black shale (OAE) section (Winterer et al., 1973) encompassing the formations of the Ontong Java, Manihiki, and Hikurangi plateaus. Similarly, the crests of Late Jurassic and Early Cretaceous seamounts in the western Pacific preserve syn-sedimentary sections deposited above the CCD (i.e., carbonate sediments).

Defining modes of eruption-constant effusion over several million years or several large pulse events over the same time interval. This will be achieved by a) age dating of discrete ash layers in syn-sedimentary sections, b) drilling through the feather edge of a LIP reached by only the largest flowstest for age progression, and c) drilling through basement reflections interpreted to represent alternating thin and thick flows (Inoue et al., 2008).

Establishing relationships among oceanic LIPs, OAEs, and other major environmental changes (e.g., ocean acidification and fertilization). Late Jurassic and Cretaceous OAEs are known to be approximately synchronous with LIP events (Jones and Jenkyns, 2001). Syn-sedimentary sections containing OAE, and bounding intervals are critical for analyses of elemental and isotopic variations associated with OAEs. These data can be compared with similar data from synchronous LIPs. Recovery of OAE intervals at multiple locations around an oceanic LIP allows directionality of fluxes to be evaluated. Knowledge of the duration of the LIP event is required for these studies (see above).

\section{Technology and LIP Drilling}

Advances in drilling technology will improve our understanding of LIP origin, emplacement, and environmental impacts dramatically. Specifically, technologies that should either be developed or implemented by the IODP that will advance our understanding of LIPs significantly include the following:

Enhanced recovery of syn-sedimentary sections, especially those with alternating hard-soft (e.g., chert-chalk) layers. To date, recovery of intercalated hard/soft sediment from the Pacific and Indian oceans has been exceedingly difficult during the DSDP, ODP, and IODP, and poor core recovery precludes recovery of important syn-sedimentary sections.

Sidewall coring, important for recovering soft sediment from alternating hard-soft layers. OAEs encompass a maximum of $150 \mathrm{~cm}$ of vertical section, although recovery of underlying and overlying sediment is necessary as well for biostratigraphic dating each OAE.

Oriented cores. Linking hotspots to LIPs, especially in the Pacific, is hampered because unoriented cores yield only paleolatitude information. Oriented cores are critical for determining sediment magnetostratigraphy in low latitudes, investigating geomagnetic field behavior, studying plate motions, and establishing flow directions of lavas.

Riser drilling in $>2500$ m of water. This will open opportunities for drilling through the feather edges of LIPs to the basement or sediment beneath, thereby bracketing the durations of LIP events.

\section{Collaborations between IODP and ICDP}

LIPs are equally well manifested in the oceans as on land. Questions such as the nature of the mantle source of volcanic 
plateaus, the ascent of magma from source to surface, magma fluxes through the life of a plateau, and the impact of LIP emplacement on global climate are best treated by a joint IODP/ICDP approach. The lessons learned from drilling on variably well exposed continental flood basalts can then be applied to the study of their more spectacular, but less accessible, oceanic counterparts. Proxies of climate change, measured in oceanic and continental sequences, provide information on the contrasting impact of the wholly submarine emplacement of an oceanic plateau and the open-to-theatmosphere impact of continental volcanism. A key target of ICDP drilling should be the sill complexes that presumably underlie most LIPs. These complexes, relatively inaccessible in ocean basins, are important for four reasons. 1) They are an important element in the magmatic plumbing of each LIP. 2) Volatile-release at sill-sediment contacts contributes greatly to climate impact. 3) Valuable deposits of $\mathrm{Ni}, \mathrm{Cu}$, and Pt-group elements are located in these sills. 4) Intrusions in sedimentary basins influence the maturation of petroleum deposits and complicate exploration for such deposits. An understanding of the sill complexes, therefore, has important economic implications, in both continental and oceanic settings. Most importantly, unique and promising opportunities exist for combined IODP/ICDP drilling of the same LIP (e.g., onshore and offshore sections of the North Atlantic Volcanic Province; the Parana-Etendeka flood basalts (South Atlantic); the Deccan Traps-Seychelles Bank dikes (Indian Ocean); in situ and obducted (Caribbean, Central and South America) Caribbean flood basalts; Alpha Ridge and the High Arctic LIP; and the Ontong Java Plateau and obducted sections thereof in the Solomon Islands (Pacific Ocean).

\section{Conclusions}

The LIPs workshop was highly successful in showing that studying LIPs requires an integrated approach involving mantle geodynamics, plume modeling, petrology, environmental impacts, paleoceanography, physical volcanology, micropaleontology, geophysics, and tectonics. The workshop also concluded that oceanic LIPs must be studied in concert with their continental counterparts to better understand emplacement mechanism and environmental effects of their emplacement. A number of conceptual drilling targets and prospective regions were identified. In addition, areas where technology development was needed were highlighted, as were potential LIP-focused IODP-industry and ICDP/IODP collaborations. The result of this workshop will allow focused IODP LIP drilling proposals to be developed.

\section{Acknowledgements}

The authors are grateful for input to this paper by the workshop participants as well as contributors who did not attend the workshop. We thank the IODP and the Consortium for Ocean Leadership for funding. Paul Lyle contributed greatly to the logistics of the workshop and led the field trip to the Causeway Coast featuring outcrops of the North
Atlantic Volcanic Province. We appreciate the reviews of this paper by Jan Behrmann, Christian Koeberl, and Hans Christian Larsen. We thank Kelly Kryc, Therese Lowe, and Charna Meth for organizing the workshop.

\section{References}

Alibert, C., 1991. Mineralogy and geochemistry of a basalt from Site 738: Implications for the tectonic history of the southernmost part of the Kerguelen Plateau. In Barron, J., Larsen, B., et al., Proc. ODP, Sci. Res., 119. College Station, Texas (Ocean Drilling Program), 293-298.

Andrews, J.F., Packham, G., et al., 1975. Initial Reports of the Deep Sea Drilling Project, 30, Washington, DC (U.S. Government Printing Office), 753 pp.

Bains, S., Corfield R.M., and Norris R.D., 1999. Mechanisms of climate warming at the end of the Paleocene. Science, 285:724-727.

Barron, J., Larsen, B., et al., 1989. Proc. ODP, Init. Rep., 119. College Station, Texas (Ocean Drilling Program), 942 pp.

Berger, W.H., Kroenke, L.W., Mayer, L.A., et al., 1993. Proc. ODP, Sci. Res., 130. College Station, Texas (Ocean Drilling Program), $867 \mathrm{pp}$.

Berner, R.A. and Kothavala Z., 2001. GEOCARB III: a revised model of atmospheric CO2 over Phanerozoic time. Am. J. Sci., 301:182-204.

Bryan, S.E., and Ernst, R.E., 2008. Revised definition of Large Igneous Provinces (LIPs). Earth-Science Rev., 86:175-202.

Bryan, S.E, Riley, T.R., Jerram, D.A., Leat, P.T., and Stephens, C.J., 2002. Silicic volcanism: an under-valued component of large igneous provinces and volcanic rifted margins. In Menzies, M.A., Klemperer, S.L., Ebinger, C.J., and Baker, J. (Eds.), Magmatic Rifted Margins. Geological Society of America Special Paper, 362:99-118.

Burke, K., and Torsvik, T.H., 2004. Derivation of Large Igneous Provinces of the past 200 million years from long-term heterogeneities in the deep mantle. Earth Planet. Sci. Lett., 227:531-538.

Coffin, M.F., 1992. Emplacement and subsidence of Indian Ocean plateaus and submarine ridges. In Duncan, R.A., Rea, D.K., Kidd, R.B., von Rad, U., and Weissel, J.K. (Eds.), Synthesis of Results from Scientific Drilling in the Indian Ocean, Geophysical Monograph 70, Washington, DC (American Geophysical Union), 115-125.

Coffin, M.F., and Eldholm, O., 1994. Large igneous provinces: Crustal structure, dimensions, and external consequences. Rev. Geophys., 32:1-36.

Coffin, M.F., Duncan, R.A., Eldholm, O., Fitton, J.G., Frey, F.A., Larsen, H.C., Mahoney, J.J., Saunders, A.D., Schlich, R., and Wallace, P.J., 2006. Large igneous provinces and scientific ocean drilling: Status quo and a look ahead. Oceanography, 19:150-160.

Coffin, M.F., Frey, F.A., Wallace, P.J., and the ODP Leg 183 Shipboard Scientific Party, 2000. Kerguelen Plateau - Broken Ridge: A large igneous province. Proc.ODP. College Station, Texas (Ocean Drilling Program), [CD-ROM].

Coffin, M.F., Pringle, M.S., Duncan, R.A., Gladczenko, T.P., Storey, M., Müller, R.D., and Gahagan, L.A., 2002. Kerguelen hotspot magma output since 130 Ma. J. Petrol., 43:1121-1139. 
Coffin, M.F., Neal, C.R., Duncan, R.A., Eldholm, O., Erba, E., Farnetani, C., Fitton, J.G., Ingle, S.P., Ohkouchi, N., Rampino, M.R., Reichow, M., Self, S., and Tatsumi, Y., 2007. Large igneous province workshop, Eos, 88:505, doi:10.1029/2007EO470009.

Courtillot, V., and Olson, P., 2007. Mantle plumes link magnetic superchrons to phanerozoic mass depletion events. Earth Planet. Sci. Lett., 260:495-504.

Cox, K.G., 1992. Continental magmatic underplating. Phil. Trans. Roy. Soc. Lond. A, 342:155-166.

Davaille, A., 1999. Simultaneous generation of hotspots and superswells by convection in a heterogeneous planetary mantle. Nature, 402:756-760.

Davies, G.F., 1994. Thermomechanical erosion of the lithosphere by mantle plumes. J. Geophys. Res., 99:15709-15722.

Duncan, R.A., Larsen, H.C., Allan, J.F., et al., 1996. Proc. ODP, Init. Rep., 163. College Station, Texas (Ocean Drilling Program), $279 \mathrm{pp}$.

Eldholm, O., and Coffin, M.F., 2000. Large Igneous Provinces and plate tectonics. In Richards, M., Gordon, R., and van der Hilst, R. (Eds.), The History and Dynamics of Global Plate Motion, Geophysical Monogr., 121, Washington, DC (American Geophysical Union), 309-326.

Eldholm, O., and Thomas, E., 1993. Environmental impact of volcanic margin formation. Earth Planet. Sci. Lett., 117:319-329.

Eldholm, O., Thiede, J., Taylor, E., et al., 1987. Proc. ODP, Init. Rep., 104. College Station, Texas (Ocean Drilling Program), 783 pp.

Eldholm, O., Thiede, J., and Taylor, E., 1989. Evolution of the Vøring volcanic margin. In Eldholm, O., Thiede, J., Taylor, E., et al. (Eds.), Proc. ODP, Sci. Res., 104. College Station, Texas (Ocean Drilling Program), 1033-1065.

Ernst, R.E., and Buchan, K.L., 2001. Large mafic magmatic events through time and links to mantle plume heads. In Ernst, R.E., and Buchan, K.L. (Eds.), Mantle Plumes: Their Identification through Time. Geol. Soc. Am. Special Paper, 352:483-575.

Farnetani, C.G., and Richards, M.A., 1994. Numerical investigation of the mantle plume initiation model for flood basalt events. $J$. Geophys. Res., 99:13813-13883.

Farnetani, C.G., and Samuel, H., 2005. Beyond the thermal plume paradigm. Geophys. Res. Lett., 32:L07311, doi:10.1029/ 2005GL022360.

Fitton, J.G., and Godard, M., 2004. Origin and evolution of magmas on the Ontong Java Plateau. In Fitton, J.G., Mahoney, J.J., Wallace, P.J., and Saunders, A.D. (Eds.), Origin and Evolution of the Ontong Java Plateau. Special Publications, 229, London, (Geological Society), 151-178.

Fitton, J.G., Mahoney, J.J., Wallace, P.J., and Saunders, A.D., 2004a. Origin and Evolution of the Ontong Java Plateau. Special Publications, 229, London (Geological Society), $374 \mathrm{pp.}$

Fitton, J.G., Mahoney, J.J., Wallace, P.J., and Saunders, A.D., 2004b. Proc. ODP, Sci. Res., 192, College Station, Texas (Ocean Drilling Program), [CD-ROM].

Frey, F.A., Coffin, M.F., Wallace, P.J., and Quilty, P.J., 2003. Proc. ODP, Sci. Res., 183. College Station, Texas (Ocean Drilling Program), [CD-ROM].

Frey, F.A., McNaughton, H.J., Nelson, D.R., Delaeter, J.R., and Duncan, R.A., 1996. Petrogenesis of the Bunbury basalt, western Australia: interaction between the Kerguelen plume and Gondwana lithosphere? Earth Planet. Sci. Lett., 176:73-89.

Gaina, C., Müller, R.D., Brown, B., Ishihara, T., and Ivanov, S., 2007. Breakup and early seafloor spreading between India and Antarctica. Geophys. J. Int., 170:151-169, doi:10.1111/j.1365246X.2007.03450.x

Gomer, B.M., and Okal, E.A., 2003. Multiple-ScS probing of the Ontong-Java Plateau. Phys. Earth Planet. Int., 138:317-331.

Herzberg, C., 2004. Partial melting below the Ontong Java Plateau. In Fitton, J.G., Mahoney, J.J., Wallace, P.J., and Saunders, A.D. (Eds.), Origin and Evolution of the Ontong Java Plateau. Special Publications, 229. London (Geological Society), 179-183.

Herzberg, C., Asimow, P.D., Arndt, N., Niu, Y., Lesher, C.M., Fitton, J.G., Cheadle, M.J., and Saunders, A.D., 2007. Temperatures in ambient mantle and plumes: Constraints from basalts, picrites and komatiites. Geochem. Geophys. Geosyst., 8: Q02006, doi: 10.1029/2006GC001390.

Hill, R.I., 1991. Starting plumes and continental break-up. Earth Planet. Sci. Lett., 104:398-416.

Hopper, J.R., Mutter, J.C., Larson, R.L., Mutter, C.Z., and Northwest Australia Study Group, 1992. Magmatism and rift margin evolution: evidence from northwest Australia. Geology, $20: 853-857$.

Ingle, S.P., and Coffin, M.F., 2004. Impact origin for the Greater Ontong Java Plateau? Earth Planet. Sci. Lett., 218:123-134.

Inoue, H., Coffin, M.F., Nakamura, Y., Mochizuki, K., and Kroenke, L.W., 2008. Intrabasement reflections of the Ontong Java Plateau: Implications for Plateau construction. Geochem. Geophys. Geosyst., 9:Q04014, doi:10.1029/2007GC001780.

Ito, G., and Clift, P., 1998. Subsidence and growth of Pacific Cretaceous plateaus. Earth Planet. Sci. Lett., 161:85-100.

Ito, G., and Taira, A., 2000. Compensation of the Ontong Java Plateau by surface and subsurface loading. J. Geophys. Res., 105:11171-11183.

Jones, C.E., and Jenkyns, H.C., 2003. Seawater strontium isotopes, oceanic anoxic events, and seafloor hydrothermal activity. Amer. J. Sci., 111:112-149.

Jones, S.M., White, N., and Maclennan, J., 2002. V-shaped ridges around Iceland: Implications for spatial and temporal patterns of mantle convection. Geochem. Geophys. Geosyst., 3(10):1059, doi:10.1029/2002GC000361.

Kennett, J.P., and Stott, L.D., 1991. Abrupt deep-sea warming, palaeoceanographic changes, and benthic extinctions at the end of the Palaeocene. Nature, 353:225-229.

Kerr, A.C., 1998. Oceanic plateau formation: a cause of mass extinction and black shale deposition around the CenomanianTuronian boundary? J. Geol. Soc. Lond., 155:619-626.

Kerr, A.C., Tarney, J., Marriner, G.F., Nivia, A., and Saunders, A., 1997. The Caribbean-Colombian Cretaceous igneous province: the internal anatomy of an oceanic plateau. In Mahoney, J.J., and Coffin, M.F. (Eds.), Large Igneous Provinces: Continental, Oceanic, and Planetary Flood Volcanism. Geophysical Monograph, 100. Washington, DC (American Geophysical Union), 123-144.

King, S.D., and Anderson, D.L., 1998. Edge-driven convection. Earth Planet. Sci. Lett., 160:289-296.

Klosko, E.R., Russo, R.M., Okal, E.A., and Richardson, W.P., 2001. 
Evidence for a rheologically strong chemical mantle root beneath the Ontong-Java Plateau. Earth Planet. Sci. Lett., 186:347-361.

Korenaga, J., 2004. Mantle mixing and continental breakup magmatism. Earth Planet Sci. Lett., 218:463-473, doi:10.1016/ S0012-821X(03)00674-5.

Korenaga, J., 2005. Why did not the Ontong Java Plateau form subaerially? Earth Planet. Sci. Lett., 234:385-399.

Kroenke, L.W., Berger, W.H., Janecek, T.R., et al., 1991. Proc. ODP, Init. Rep., 130. College Station, Texas (Ocean Drilling Program), 1240 pp.

Kuroda, J., Ogawa, N.O., Tanimizu, M., Coffin, M.F., Tokuyama, H., Kitazato, H., and Ohkouchi, N., 2007. Contemporaneous massive subaerial volcanism and late Cretaceous Oceanic Anoxic Event 2. Earth Planet. Sci. Lett., 256:211-223.

Larsen, H.C., Duncan, R.A., Allan, J.F., and Brooks, K., 1999. Proc. ODP, Sci. Res., 163. College Station, Texas (Ocean Drilling Program), 173 pp.

Larsen, H.C., Saunders, A.D., Clift, P.D., et al., 1994. Proc. ODP, Init. Rep., 152. College Station, Texas (Ocean Drilling Program), 977 pp.

Larson, R.L., 1991. Latest pulse of Earth: evidence for a midCretaceous superplume. Geology, 19:547-550.

Larson, R.L., and Erba, E., 1999. Onset of the mid-Cretaceous greenhouse in the Barremian-Aptian events: Igneous events and the biological, sedimentary, and geochemical responses. Paleoceanogr., 14:663-678.

Leckie, R.M., Bralower, T.J., and Cashman, R., 2002. Oceanic anoxic events and plankton evolution: Biotic response to tectonic forcing during the mid-Cretaceous. Paleoceanogr., 17(3):10.1029/2001PA000623.

Mahoney, J.J., and Coffin, M.F., 1997. Large Igneous Provinces: Continental, Oceanic, and Planetary Flood Volcanism. American Geophysical Union Geophysical Monograph 100. Washington, DC (American Geophysical Union), 438 pp.

Mahoney, J.J., Duncan, R.A., Tejada, M.L.G., Sager, W.W., and Bralower, T.J., 2005. Jurassic-Cretaceous boundary age and mid-ocean-ridge-type mantle source for Shatsky Rise. Geology, 33:185-188, doi:10.1130/G21378.1.

Mahoney, J.J, Fitton, J.G., and Wallace, P.J. et al., 2001. Basement drilling of the Ontong Java Plateau, Sites 1183-1187, 8 September-7 November, 2000. Proc. ODP Init. Rep., 192. College Station, Texas (Ocean Drilling Program), 75p.

Miller, K.G., Kominz, M.A., Browning, J.V., Wright, J.D., Mountain, G.S., Katz, M.E., Sugarman, P.J., Cramer, B.S., ChristieBlick, N., and Pekar, S.F., 2005. The Phanerozoic record of global sea-level change. Science, 310:1293-1298.

Mutter, J.C., Buck, W.R., and Zehnder, C.M., 1988. Convective partial melting: 1. A model for the formation of thick basaltic sequences during the initiation of spreading. J. Geophys. Res., 93:1031-1048.

Nakagawa, T., and Tackley, P.J., 2005. The interaction between the post-perovskite phase change and a thermo-chemical boundary layer near the core-mantle boundary. Earth Planet. Sci. Lett., 238:204-216.

Neal, C.R., Mahoney, J.J., Kroenke, L.W., Duncan, R.A., and Petterson, M.G., 1997. The Ontong Java Plateau. In Mahoney, J.J., and Coffin, M.F. (Eds.), Large Igneous Provinces: Continental, Oceanic, and Planetary Flood Volcanism. Geophysical
Monograph, 100. Washington, DC (American Geophysical Union), 183-216.

Operto, S., and Charvis, P., 1995. Kerguelen Plateau: a volcanic passive margin fragment? Geology, 23:137-140, doi:10.1130/00917613(1995) 023<0137:KPAVPM>2.3.CO;2

Parsons, B., and Sclater, J.G., 1977. An analysis of the variation of ocean floor bathymetry and heat flow with age. J. Geophys. Res., 82:803-827.

Peate, I.U., Baker, J.A., Kent, A.J.R, Al-Kadasi, M., Al-Subbary, A., Ayalew, D., and Menzies, M., 2003. Correlation of Indian Ocean tephra to individual Oligocene silicic eruptions from Afro-Arabian flood volcanism. Earth Planet. Sci. Lett., 211:311-327.

Planke, S., Symonds P.A., Alvestad E., and Skogseid, J., 2000. Seismic volcanostratigraphy of large-volume basaltic extrusive complexes on rifted margins. J. Geophys. Res., 105:19335-19351, doi:10.1029/1999JB900005.

Poore, H.R., Samworth, R., White, N.J., Jones, S.M., and McCave, I. N., 2006. Neogene overflow of Northern Component Water at the Greenland-Scotland Ridge. Geochem. Geophys. Geosyst., 7:Q06010, doi:10.1029/2005GC001085.

Rampino, M.R., and Stothers, R.B., 1988. Flood basalt volcanism during the past 250 million years. Science, 241:663-668.

Reymer, A., and Schubert, G., 1984. Phanerozoic addition rates to the continental crust and crustal growth. Tectonics, 3:63-77.

Richardson, W.P., Okal, E.A., and van der Lee, S., 2000. Rayleighwave tomography of the Ontong Java Plateau. Phys. Earth Planet. Int., 118:29-51.

Roberge, J., Wallace, P., White, R.V., and Coffin, M.F., 2005. Anomalous subsidence of the Ontong Java Plateau inferred from CO2 contents of submarine basaltic glasses. Geology, 33:501-504.

Roberts, D.G., Schnitker, D., et al., 1984. Initial Reports, Deep Sea Drilling Project, Leg 81, Washington, D.C. (U.S. Government Printing Office), 923 pp.

Sano, T., and Yamashita, S., 2004. Experimental petrology of basement lavas from Ocean Drilling Program Leg 192: implications for differentiation processes in Ontong Java Plateau magmas. In Fitton, J.G., Mahoney, J.J., Wallace, P.J., and Saunders, A.D. (Eds.), Origin and Evolution of the Ontong Java Plateau. Special Publications, 229. London, (Geological Society), 185-218.

Saunders, A.D., Larsen, H.C., and Wise, S.W., Jr., 1998. Proc. ODP, Sci. Res., 152. College Station, Texas (Ocean Drilling Program), $554 \mathrm{pp}$.

Schlanger, S.O., and Jenkyns, H.C., 1976. Cretaceous anoxic events: causes and consequences. Geologie en Mijnbouw, 55: $179-184$.

Schlich, R., Wise, S.W., Jr., et al., 1989. Proc. ODP, Init. Rep., 120. College Station, Texas (Ocean Drilling Program), 648 pp.

Self, S., Keszthelyi, L., and Thordarson, T., 1998. The importance of pahoehoe. Ann. Rev. Earth Planet. Sci., 26:81-110.

Self, S., Widdowson, M., Thordarson, T., and Jay, A.E., 2006. Volatile fluxes during flood basalt eruptions and potential effects on the global environment: A Deccan perspective. Earth Planet. Sci. Lett., 248:517-531.

Sepkoski, J.J., 1996. Patterns of Phanerozoic extinction: a perspective from global data bases. In Walliser, O.H. (Ed.), Global Events and Event Stratigraphy. Berlin (Springer), 35-51. 
Snow, L.J., Duncan, R.A., and Bralower, T.J., 2005. Trace element abundances in the Rock Canyon Anticline, Pueblo, Colorado, marine sedimentary section and their relationship to Caribbean plateau construction and oxygen anoxic event 2. Paleoceanogr, 20:PA3005, doi:10.1029/2004PA001093.

Srivastava, S.P., and Tapscott, C.R., 1986. Plate kinematics of the North Atlantic. In Tucholke, B.E., Vogt, P.R. (Eds.), The Geology of North America. The Western Atlantic Region, $D N A G$ Series vol. M. Boulder, Colo. (Geological Society of America), ,379-404.

Stagg, H.M.J., Colwell, J.B., Borissova, I., Ishihara, T., and Bernardel, G., 2006. The Bruce Rise Area, East Antarctica: formation of a continental margin near the Greater India-AustraliaAntarctica triple junction. Terra Antartica, 13:13-22.

Stein, C.A., and Stein, S., 1992. A model for the global variation in oceanic depth and heat flow with lithospheric age. Nature, 359:123-129.

Storey, M.S., Kent, R., Saunders, A.D., Salters, V.J., Hergt, J., Whitechurch, H., Sevigny, J.H., Thirlwall, M.F., Leat, P., Ghose, N.C., and Gifford, M., 1992. Lower Cretaceous volcanic rocks on continental margins and their relationship to the Kerguelen Plateau. In Wise, S.W., Jr., Schlich, R., et al. (Eds.), Proc. ODP, Sci. Res., 120. College Station, Texas (Ocean Drilling Program), 33-53.

Stothers, R.B., 1998. Far reach of the tenth century Eldgjá eruption, Iceland. Climatic Change, 39:715-726.

Svensen, H., Planke, S., Malthe-Sorenssen, A., Jamtveit, B., Myklebust, R., Eidem, T.R., and Rey, S.S., 2004. Release of methane from a volcanic basin as a mechanism for initial Eocene global warming. Nature, 429:542-545.

Symonds, P.A., Planke, S., Frey, Ø., and Skogseid, J., 1998. Volcanic evolution of the Western Australian continental margin and its implications for basin development. In Purcell, P.G.R.R. (Ed.), The Sedimentary Basins of Western Australia 2: Proceedings of the PESA Symposium. Perth, Australia (Petroleum Exploration Society of Australia), 33-54.

Tackley, P.J., 1998. Three-dimensional simulations of mantle convection with a thermo-chemical basal boundary layer: $\mathrm{D}^{\text {"? In }}$ Gurnis, M. (Ed.), The Core-mantle Boundary Region, Geophys. Monogr. Ser., 28. Washington, DC (American Geological Union), 231-253.

Tajika, E., 1998. Climate change during the last 150 million years: reconstruction from a carbon cycle model. Earth Planet. Sci. Lett., 160:695-707.

Thomas, E., 1992. Cenozoic deep-sea circulation: Evidence from deep-sea foraminifera. In Kennet, J.P., and Warnke, D. (Eds.), The Antarctic Paleoenvironment: A Perspective on Global Change, Antarct. Res. Ser. 56. Washington, D.C. (American Geological Union), 141-165.

Thordarson, T., 2004. Accretionary-lapilli-bearing pyroclastic rocks at ODP Leg 192 Site 1184: A record of subaerial phreatomagmatic eruptions on the Ontong Java Plateau. In Fitton, J.G., et al., (Eds.), Origin and Evolution of the Ontong Java Plateau. Spec. Pub. 229. London (Geological Society), 275-306.

Winterer, E.L., Ewing, J.I., et al., 1973. Init.Rep. Deep Sea Drill. Proj. Washington, DC (U.S. Government Printing Office), 17:1-931.

Wise, S.W., Jr., Schlich, R., et al., 1992. Proc. ODP, Sci. Res., 120. College Station, Texas (Ocean Drilling Program), 1155 pp.
Wright, J.D., and Miller, K., 1996. Control of North Atlantic Deep Water circulation by the Greenland-Scotland Ridge. Paleoceanogr., 11:157-170.

\section{Authors}

Clive R. Neal, Department of Civil Engineering and Geological Sciences, 156 Fitzpatrick Hall, University of Notre Dame, Notre Dame, Ind., 46556, U.S.A., e-mail: neal.1@nd.edu.

Millard F. Coffin, National Oceanography Centre, Southampton, University of Southampton Waterfront Campus, European Way, Southampton SO14 3ZH, U.K.

Nicholas T. Arndt, Laboratoire de Géodynamique des Chaînes Alpines, Université de Grenoble, Grenoble, France.

Robert A. Duncan, College of Oceanic and Atmospheric Sciences, 104 COASAdmin Bldg., Oregon State University, Corvallis, Ore. 97331, U.S.A.

Olav Eldholm, Department of Earth Science, The University of Bergen, Allegaten 41, N-5007, Bergen, Norway.

Elisabetta Erba, Dipartimento di Scienze della Terra, University of Milan, via Mangiagalli, 34, 20133 Milano, Italy.

Cinzia Farnetani, Laboratoire de Dynamique des Fluides Géologiques, Institut de Physique du Globe, Boite 89, 4 pl. Jussieu, 75252 Paris, France.

J. Godfrey Fitton, School of Geosciences, 210 Grant Institute, University of Edinburgh, The King's Buildings, West Mains Road, Edinburgh EH9 3JW, U.K.

Stephanie P. Ingle, National Oceanography Centre, Southampton, University of Southampton Waterfront Campus, European Way, Southampton SO14 3ZH, U.K.

Nao Ohkouchi, Institute for Research on Earth Evolution, Japan Agency for Marine-Earth Science Technology, 2-15 Natsushima-Cho, Yokosuka, 237-0061, Japan.

Michael R. Rampino, Earth \& Environmental Science Program, New York University, 1009 Silver Center, 100 Washington Square East, New York, N.Y. 10003, U.S.A.

Marc K. Reichow, Department of Geology, University of Leicester, University Road, Leicester, LE1 7RH, U.K.

Stephen Self, Department of Earth Sciences, The Open University, Milton Keynes MK7 6BJ, U.K.

Yoshiyuki Tatsumi, Institute for Research on Earth Evolution, Japan Agency for Marine-Earth Science Technology, Natsushima-cho 2-15, Yokosuka 237-0061, Japan. 